\title{
Collaborative Governance in Eradicating Corruption in Indonesia: Challenges and Opportunities
}

\author{
Azwar Abubakar \\ Faculty of Administrative \\ Science \\ University of Indonesia \\ azwar.abubakar1952@gmail.c \\ om
}

\author{
Eko Prasojo \\ Faculty of Administrative \\ Science \\ University of Indonesia \\ e_prasojo@yahoo.com
}

\author{
Lina Miftahul Jannah \\ Faculty of Administrative \\ Science \\ University of Indonesia \\ linamjannah@gmail.com
}

\begin{abstract}
Corruption is one of the fundamental problems in Indonesia. Ineffective efforts to eradicate corruption are influenced by the lack of synergy among stakeholders. This study aims to describe the factors affecting collaborative governance in eradicating corruption in Indonesia. The approach used is post-positivist with mix method data collection techniques through existing statistics and in-depth interviews. There were some factors affecting the collaboration in eradicating corruption in Indonesia. First, despite mutual agreement among upholders about corruption eradication commision establishment, conflicts among upholders occurred. They happened because of Corruption Eracidication Commision's (KPK) investigation strategies. This disturbs their esprits de corps and the cases involving prosecutors or policemen resulted in conflicts of interests. Nevertheless, in other cases, some of their cooperation have been built. Second, leadership has affected the collaboration. There were some factors influencing the leadership skills, such as knowledge, experience in bureaucracy, political will, communication skills to produce engagement, psychological conditions, human resources management skills, and power distribution. Thirdly, imbalances of power, human resources, knowledge, and infrastructures has appeared and it potentially become collaborative incentives. Nevertheless, leaders have not completely reaped its benefits. Moreover, there is an integrity imbalance among upholders that results in low trust building. Upholders have not yet held a massive improvement in integrity. Fourth, There is no grand strategy of corruption eradication which regulates reliable actions with clear trajectory, time coverage, responsible stakeholders, and measurable objectives. They have established a Memorandum of Understanding among upholders and mid term and short term national eradicating corruption strategies, but it could not fully be implemented under the collaborative circumstances. Fifth, each upholders's institutional design affects their independence in operational levels. Sixth, the perspective that KPK is not include in executive actors, consequently, the other institutions have not yet encouraged to fully participate in collaborative process.
\end{abstract}

\section{Keywords: Collaborative Governance, Corruption, Eradication \\ I. INTRODUCTION \\ One of the Sustainable Development Goals (SDGs)} of 2030 is Peace, Justice, and Strong Institutions. This goal can be achieved by significantly reducing corruption and bribery in all their forms. Corruption eradication is also the implementation key of sustainable development in Indonesia, endorsed by the Director of Transparency International Indonesia (TII) Program, Ilhan Saenong who believes that the SDGs are threatened to fail if corruption is still excessive because development financing will be effective only if corruption is prevented and reduced.

Compared with other countries, the Indonesian corruption index is low. Based on the research of Transparency International in 2016, Indonesia ranks 88 out of 168 countries in the Corruption Perceptions Index 2016. Corruption occurs in almost every element of state administration. Law no. 20 of 2001 on Corruption Eradication undoubtedly states that corruption that has been happening extensively, not only harms the state finances, but also violates the social and economic rights of the community. The complexity of corruption problems with the involvement of various actors has led to a different approach in combating corruption in each country.

Collaboration analysis can be reviewed using the concept of collaborative governance. Ansell and Gash (2007:2) define collaborative governance as a governance arrangement whereby one or more government agencies directly involve non-governmental stakeholders in a formal, agreement-oriented, consultative consensual decisionmaking process aimed to create or implement public policies or run public programs or assets. Moreover, Emerson and Balog (2011) explained that collaborative governance as the processes and structures of public policy decision making and management which engrossed people constructively 
across the boundaries of public agencies, levels of government, and or the public, private and civic spheres, to achieve a public purpose that could not otherwise be overcome. Based on these definition, some principles of collaborative governance, such as 1) forum is initiated by public agency, organized formally, met collectively, and aimed to make concensus; 2) stakeholders are included external public actors; 3) all stakeholders are involved directly in policy making; 4) its focus is public policy and management. Through this collaboration, Andrew Campbell and Michael Gould (1999, 3-4) stated it resulted in knowledge and resources sharing; collection power of negotiation; coordinating strategies; vertical integration; new products, organizations, alliances, shared attempts (Robert Agranoff, 15).

The importance of coordination and cooperation among institutions involved in combating corruption is evidenced by the establishment of specific institutions in charge of coordination between these institutions in several countries. Uganda, South Africa, Bulgaria, Georgia and New South Wales built distinguished agencies that coordinate other corruption eradication agencies (Transparency International, 2017). Nevertheless, cooperation and coordination have not been seen in practice of combating corruption in Indonesia. Based on UU No 30 2002, Corruption Eracidication Commission (KPK) is mandated to be an coordinating agency. The collective agreement was established between the Attorney of the Republic of Indonesia, the Police of the Republic of Indonesia and the Corruption Eradication Commission on the Optimization of the Eradication of Corruption which was signed on March 29, 2012 (Number: KEP049/A/JA/03/2012, Number: B/23/III/2012, Number: Spj39/01/03/2012). Despite having mutual agreement, the Indonesian National Police (POLRI) and KPK are still in conflict because of offending their esprits de corps.

The absence of inter-institutional collaboration involved in combating corruption in Indonesia raises the need for an analysis of factors that influence collaborative governance. Actually, there are some studies elaborating collaborative governance, but this study is unique in the sense that collaborative governance does not only combat corruption outside actors involved in governance, but also combats it in their organizations. Hence, there arises a conflict of interest when building collaborative governance in combating corruption. Therefore, this study aims to describe factors affecting collaborative governance in combating corruption in Indonesia. Furthermore, this research can enrich the treasury of public administration science, in particular collaborative governance. The main thesis of this paper is that collaboration did not occur because 1) there was no facilitative leadership among institutions; 2) human resources of the upholders that have integrity and commitment is merged with those who have no integrity and commitment; 3) KPK that plays a role as coordinator and supervisor did not use a trajectory approach for developing the other upholders; 4) KPK has not yet triggered the state and non state institutions in preventing corruption

\section{METHOD}

The research approach is a post-positivist approach which uses a deterministic philosophy in which the causes determine its effects, so that the problems studied reflect the need to identify and assess the causes that affect the impact in the experiment. Data is collected by mixed methods through existing statistics and in-depth interviews. Initially, the researcher conducted the collection of strategic data and statistics from public documents provided by government or private agencies related to the corruption eradication. After that, the researcher conducted an analysis of secondary data and conducted in-depth interviews with several informants, law enforcement officials, ministries / agencies, NGOs, and academics to elaborate the facts in combating corruption. These two methods produced data illustrating the influential factors in the relationship among institutions. To ensure the validity and reliability of field findings, this study used appropriate triangulation, peer-checking, and reference methods.

Some theories used are institutional theories, corruption, and collaborative governance model. This research analyzes relations between institutions in combating corruption by describing the variables in collaborative governance and the factors influencing the collaborative governance delivered by Ansell and Gash (2007). This concept consists of five variables: the initial condition variable consisting of the knowledge and power imbalance, the incentives and limitations to participate, and the history of cooperation and conflict; institutional design variables; facilitative leadership variables, the cooperative process variables consisting of face-to-face dialogue, trust building, commitment to the process, and mutual understanding; and intermediate outcomes variable.

The data analysis technique used is successive approximation. Based on Neuman (2007: 338), the researcher looks at the extent to which the concept is consistent with the facts found in the prevention and eradication of corruption. So it is possible that the factors found are not covered by collaborative governance theory.

\section{RESULTS}

The relations among the institutions involved in combating corruption in Indonesia are influenced by several factors that also influence the formation of collaboration. Firstly, the relationship is influenced by the initial condition of the institution. This initial condition can be seen through a massive corruption condition. It could be observed in the number of corruption cases conducted by actors according to their professions. 
The Number of Corruption Cases 1115

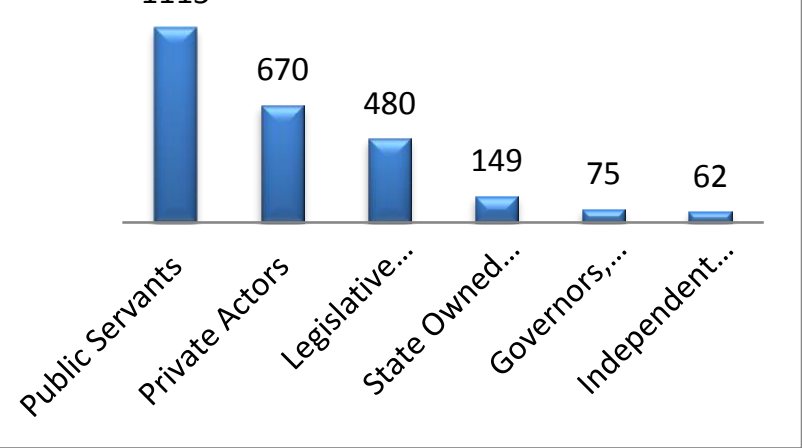

Chart 1 The Number of Corruption Cases

Source: Kompas, 2016

According to the bar chart 1 , public servants is the profession which has the highest number of actors conducting corruption cases. Following this, 670 private actors and 480 legislative actors carried on the corruption cases and the lowest was category of independent actors.

Furthermore, the initial conditions were also influenced by the occuring conflicts and cooperation; imbalance of power, resources, and knowledge; as well as the incentives and limitations to collaborate. Identifying from its history, the KPK establishment began with the meeting of several actors involved in combating corruption such as the Indonesian State Police (POLRI) and the Attorney General. This shows that POLRI and the Attorney General agreed to form KPK. Conflicts occurred along with the KPK duties implementation. The KPK has been in conflict with the Attorney because it reopened the cases that had been handled by the Attorney. This move made the Attorney, which also acted as an upholder, offended. Conflict with POLRI began when KPK handled Susno Duaji's case. The conflicts between KPK and the Police are often triggered by KPK's initiative to litigate corruption cases related to POLRI.

The second factor influencing inter-relationship in combating corruption is the imbalance of power, human resources, knowledge, and facilities among institutions. Differences in authority cause an imbalance of power. This could be observed in their authority for wiretapping. KPK can wiretap without asking for permission, while POLRI must request court permission to do so. However, there is no clear rule distinguishing upholder authorities in a litigation process, so it cannot be ensured that a case can only be handled by an upholder.

Imbalances in quantity and quality human resources also influence the relationships between actors. Upholder integrity was still low, as evidenced by some irregularities that occurred during the litigation process. Differences in quality of human resources resulted from several causes, namely the quality of recruitment, budgeting system, interaction arrangement system and the implementation process of each institution's work is still different, and also the organizational structure that is vulnerable to intervention. The human resources quality is also influenced by knowledge imbalance, in particular different levels of technical knowledge about corruption. In addition, the corruption court judges were still lacking experience in handling corruption cases. Differences in the facilities and infrastructure ownership also affected the imbalance. For example, the detection tools are only held at the POLRI Headquarters with a limited number at local levels, so that local law enforcement was not optimal.

Imbalances of power, human resources, and facilities and infrastructure can be incentives to participate. KPK has the authority to take over cases previously handled by POLRI and the Attorney, by the authority, KPK can assist the Attorney in handling cases that are vulnerable to intervention. Some executives are involved in the President's Instructions on corruption eradication (Inpres PPK). For example, POLRI participates in online system about letter that informs investigation start (SPDP Online) because it can contribute to the achievement of institutional goals. This becomes an incentive to participate in the Inpres PPK. There are no clear rules regarding the restrictions on cases handled by each upholder. KPK Law mentions that KPK not only focus on grand corruption, but also corruption involving state officials, so that the amount of state losses is not the only indicator. The regulations increase cooperation opportunities for the handling cases. On the other hand, there are several restrictions to participate: 1) there is no data about the number of corruption cases handled by each upholder, so that each institution does not know the cases being handled by other institutions and the cooperation opportunities in handling corruption cases; 2) KPK is seen as an outsider in the Inpres PPK.

The second variable affecting collaboration for corruption eradication is the collaborative process. The collaborative process has occurred in conducting investigations and OTT between POLRI and KPK. POLRI also invited KPK experts to conduct litigation of corruption criminal acts. The Attorney, POLRI, and KPK cooperated in reporting SPDP, but it was conducted maximally. In some cases, the friction still occurred among upholders. KPK also cooperated with the Ministry of Finance in the development of a whistleblower system. Moreover, NGO are involved in cooperation to combat corruption. For example, Indonesian Corruption Watch collaborated with KPK and executives in giving input about upholders performance.

The third variable is facilitative leadership. The leadership of each institution still has low maturity and main tasks and functions understanding. It can be seen from the lack of coordination and supervision conducted by KPK. Leadership difference is influenced by knowledge differences of bureaucratic anatomy, experience in cooperation with bureaucracy, and co-management. Individual ego and ambition to perform also affected the 
cooperation. Leaders who are able to lower their ego and manage communication relationships with other leaders can reduce the risk of miss-communication and enhance cooperation opportunities. On the other hand, low commitment and political will of each leader also caused the low desire of subordinates to cooperate. Commitment and political will are influenced by the leader's integrity and track record. A leader's background determines the ability to build cooperation. Leaders with political party background can interrupt the dependability and cooperation opportunity.

Corruption eradication has not been centrally managed. Based on his authority, the president can encourage POLRI, the Attorney General, and KPK to cooperate, especially in terms of human and financial management without intervening litigation process. The president currently has the commitment and political will to combat corruption, particularly corruption prevention. In addition, the role of the Coordinating Minister for Political, Legal, and Security Affairs in leading anti-corruption action appears to be less. It can be seen from his role in coordinating the institutions involved in anti-corruption actions.

The forth variable influencing collaborative governance among institutions is institutional design. It can be realized from (1) the existence of a regulatory system of relationship between KPK, other upholders, and executives and local government that encouraged collaboration called the National Strategy on Corruption Eradication (Stranas PPK), but has not been able to create the essential collaboration; (2) the institutional process absence of POLRI and the Attorney General which create independence; (3) there is an Memorandum of Understanding (MoU) between upholders containing SPDP Online; (4) the structure of APH was not compatible with its prevention function; (5) there is no grand strategy against corruption, Stranas PPK was not seen to be sufficient strategy.

Other factors affecting collaboration among institutions are (1) the top-down POLRI culture that causes difficulties in internal organizational improvement and bottom-up cooperation processes; (2) Instead of being partners, KPK considers other upholders as the law enforcement objects. One of the Stranas PPK outputs does not reflect the target to be achieved in combating corruption, namely the creation of the law enforcement index during the previous administration period.

\section{DISCUSSION}

Firstly, analysing previous conflicts and cooperation among institutions, it was found that KPK has the opportunity to be a collaborative initiator among corruption eradication actors. Nevertheless, KPK's authority which is greater compared to that of other upholders tends to make it arrogant and less motivated to cooperate with other institutions. KPK often conducts corruption eradication independently without encouraging other officers to collaborate. This is indicated by the coordination and supervision functions that have not been implemented optimally by KPK. Nevertheless, human resource imbalances occurring among upholders can increase collaboration if leaders have a working paradigm to complement each other and if there is a clear division of labor. In terms of human resource imbalances, collaboration can be achieved if there is improvement in human resource management, especially human resources related to eradicating corruption.

The second factor influencing relations among the institutions is the collaboration process. This process consists of dialogue or communication among actors, trust building, commitment in collaborative processes, and mutual understanding. The process of collaboration has occurred in the investigation and OTT between POLRI and KPK in which POLRI invited KPK experts. The Attorney General, POLRI and KPK cooperated in reporting the SPDP. However, KPK lacks feedback in the reported SPDP. In fact, this is regulated in the Law and the Criminal Code. To overcome the problem and to implement Inpres PPK, KPK and POLRI have cooperated in building SPDP online. Based on Inpres PPK, POLRI is responsible for building the SPDP system, but based on the KPK Law, KPK is in charge of supervising SPDP, so there is no compliance between the Law and Inpres PPK. This is also because KPK is outside the government, and so Inpres PPK cannot force KPK. This can lead to miss-communication among the two institutions and impact the collaboration process.

In handling cases involving the suspects from upholders, the KPK communicated with the head of the upholders, but they did not take much action through law enforcement. Furthermore, communication between KPK and executives was not taking place. This was influenced by the communication style of KPK with the executives' communication style that could not lead to sense of equality and engagement. Hence, the executives did not feel dictated. The communication strategy between KPK and the community that tends to convey the litigation process through the media could lead to conflict between KPK and executive actors suspected by KPK. For cases involving POLRI personnel, this could offend their Esprits De Corps, and thus may cause conflict among the institutions. The political and technocratic approach can be one of strategies to overcome it.

Meetings that discuss common goals and targets have not been initiated by upholders. These joint goals and targets include internal and external improvements. Such meetings are essential to formulate the stages of improvements in terms of action stages and time coverage, resulting in a clear agenda for each upholder. These meetings could build a shared understanding of the corruption eradication action, and accordingly, have the same view of the speed and perspective in preventing and prosecuting corruption. 
There are also different perspectives in implementing corruption prevention strategies. First, the institutions that choose to implement programs using the "pilot project"concept could implemented better -defined programs. Secondly, institutions that choose prevention programs are introduced to all executives actors could implement less stringent program. For example, the KPK implemented Visio, while the Ministry of Administrative and Bureaucracy Reform (Ministry of PAN RB) implemented the Policy of Regional Medium Term Development Plan (RPJMD). Substantially, these activities have similarities, but the results were not maximal because they were not implemented collaboratively. Over-lapping is due to the lack of knowledge of programs conducted by other institutions and bureaucratic functions and sufficient experience to maximize the trigger mechanism. In fact, KPK is respected by the executives. When the KPK gives instructions to implement certain programs, the local government will follow the instructions even though they know that the program has similarities with the programs undertaken by the Ministry of PAN RB. Because of the lack of coordination between these institutions, checks and balances have not occurred in the programs with the same focus.

On the other hand, KPK has conducted a joint study with several executives in preventing corruption. This could increase the institutional cooperation commitment because of mutual understanding. It was conducted in the improvement of the BPJS system with the Ministry of Health. KPK also conducted an early warning detection system for executives in order to implement a corruption prevention strategy. Nevertheless, these strategies are not applied to all executives due to the limited human resources. Communication between KPK and the executives to make regulations is important so that the violation of KPK's appeal may be subject to administrative sanctions. Consequently, joint action between KPK and executives is an important factor to achieve the effectiveness of prevention strategies.

In addition, the eradication of corruption is more viewed as an issue, not as an agenda. Viewing corruption eradication as an agenda could enhance cooperation because medium and long-term opportunities and challenges are considered. Moreover, each institution has different targets of corruption to eradicate. KPK considers the public trust index as its performance indicator, but other stakeholders judge using the corruption perception index. It leads to differences in upholders corruption eradication strategies.

Institutional commitment has been established to accelerate the eradication of corruption cases. An example of this is the commitment of Jampidsus to speed up the suspended cases. This is an opportunity to increase cooperation. Currently, the commitment to cooperate through the MoU of the Attorney General, Police and KPK has been made, but the operationalization of the technical directions has not been well-established. Commitment in the collaboration process is determined by the upholders' interests. One of the Prosecutors of KPK stated that every institution conducts the action in accordance with its own corruption fighting identity. Therefore, when agencies do not have the same fighting identity, collaboration is difficult to establish. The interest in the Attorney and Police Department are influenced by intervention. Improvements in the range of Career Development control and improved transparent and accountable recruitment systems need to be undertaken to resolve this issue.

Commitment is also influenced by individual integrity and Esprits De Corps. The weak political will be led from not-established massive and structured integrity improvements within the police force. The police and prosecutor are also influenced by external intervention in the litigation process. This intervention causes private interest to be higher than the institutional interest so that the organization's internal positive collaboration could face an obstacle.

The joint action in eradicating corruption has also been influenced by the belief in corruption eradication strategy effectiveness. There were stakeholders who believed in short and medium term eradication of corruption in the, but there are stakeholders who are not sure about eradicating corruption because it has become a culture. This belief is influenced by the facts in the field faced by each informant. Their conviction affects the motivation that impacts on the commitment to eradicate corruption.

There are many cooperation opportunities among institutions. Initially, in Stranas PPK implementation, BPK was able to evaluate its performance. Furthermore, to reduce corruption in goods and services procurement, LKPP, the Ministry of Public Works and the Ministry of Finance can cooperate in determining the minimum price of goods and services. It can also reduce the corruption gap in procurement. Besides, the government can also cooperate with multinational companies in order to formulate corruption pevention in goods and services procurement. Moreover, the other actors who can be invited to be involved in the joint action are NGOs, consultant associations, and the Indonesian Chamber of Commerce and Industry. NGOs can engage in knowledge sharing.

Third, the factors affecting collaboration in eradicating corruption is leadership. Sufficient leaders' knowledge could encourage collaboration among corruption eradication institutions. Firstly, leader knowledge and understanding of the main tasks and functions can maximize the collaboration in eradicating corruption. This can be seen from KPK's authority to carry out coordination and supervision. Through their knowledge and understanding, KPK leaders can further encourage relevant institutions to be involved in eradicating corruption. Secondly, knowledge about bureaucratic functions can encourage KPK to maximize trigger mechanisms in its prevention strategies. Hence, they know the cooperation opportunities. Third, the 
leader's knowledge of problems in eradicating corruption help to determine the eradication strategies. This knowledge is influenced by listening limitations of the leaders, which thus limits the information available for directing the right eradicating corruption strategy. This limitation is also exacerbated by the actors interest in providing information. In Stranas PPK, leaders are not aware of its strategic role and objective, and thus, guidance was not given in implementing Stranas PPK.

Another factor affecting leadership is the leaders' bureaucracy experience, especially the KPK leaders. Leaders with their experience knowledge of how the bureaucracy works, thus, encourage cooperation in corruption eradication. In addition, the experience of leaders who have "players" in corruption also hamper corruption prevention actions or even close opportunities for cooperation.

Political will of leaders can also encourage collaboration in corruption eradication. Currently, the president's political will in corruption prevention is stronger. This can encourage cooperation between the ministries and KPK because only KPK as upholders has a structure supporting corruption prevention. To maintain collaboration sustainability, a strong and consistent commitment is required. In addition, exemplary leaders can also encourage subordinates to eradicate corruption. This can boost the minister's push because structurally, the ministers are under the president. The president can also provide penalties directly to ministers who can not cooperate in eradicating corruption. Political will is also not only owned by the president, but also owned by the leadership of institutions fighting corruption. This can be seen from the MoU for cooperation in eradicating corruption between KPK, the Attorney General and POLRI. This can provide positive energy in eradication cooperation among upholders.

Leaders with good communication skills can also influence the cooperation that exists among corruption eradication institutions. Leaders who are able to manage communication relationships with other leaders can reduce the risk of miss-communication and increase cooperation opportunities.

In addition, the president through the Inpres PPK that is issued annually can provide strategic direction regarding its targets. In Stranas PPK implementation, its leading actor can not been seen. Currently, there is only one vocal point that is Bappenas. Good communication between the president and the heads of the corruption eradication institutions can increase cooperation in eradicating corruption. In addition to the president, the leaders' ability in attribution, delegation and mandate can also increase internal cooperation so as to improve internal conditions and external cooperation.

Fourth, the factors that influence the occurrence of collaboration in eradicating corruption is the institutional design. In the context of corruption eradication in Indonesia, upholders have made basic rules in building collaboration through MoU. This can improve the collaboration process as it enhances the clarity of each upholder's role in agreed actions that impact the effectiveness of collaboration and outcomes of the collaborative process. An important factor of the existence of this basic rule is the consistency of the agenda from one regime to the next so that the actions undertaken in the basic rules can be sustainable and can increase the effectiveness of corruption eradication.

Institutional design is also seen from the role clarity of each stakeholder. Based on KPK Law, KPK has a clear role in implementing the trigger mechanism. This function is realized by using the KPK's authority in supervising and coordinating other upholders thus enhancing cooperation opportunities. However, this coordination and supervision function has not been systematically felt by upholders. In terms of prevention, the KPK performs coordination functions by conducting police and attorney system analysis. Based on the results of the analysis, KPK provides inputs for their internal improvement. On the other hand, the KPK is not a political institution, but on several occasions, their statements had political content, particularly their response to parties that did not support the inquiry right. Institutionally, the KPK has a leader who has weak control over bureaucratic actors. This affects corruption prevention and litigation implementation so as to affect the collaboration opportunities with other institutions. It also indicates that to cooperate with the KPK, not only requires political will of their leader, but also the commitment of high official in the bureaucracy.

\section{CONCLUSION}

In conclusion, to overcome a massive corruption, various corruption actors came from different level of government, and low integrity of upholders, collaborative governance against corruption was affected by some distinctive factors. To build collaborative governance against corruption, stakeholders' integrity, case handling style, shared grand strategy are needed.

Based on the previous conflicts and cooperation in eradicating corruption, the KPK can be an initiator of collaboration. To prepare a joint agenda in eradicating corruption, stakeholders should have joint meeting to arrange action plans. These activities are supported by facilitating leaders, for instance, leaders who have sufficient knowledge and can build engagement. In addition, upholders must also improve the integrity through island of integrity and do institutional arrangement to improve their independency; and commitment of its human resources. To enhance the collaborative governance, the president as the top leader should contribute directly in leading the collaboration. As chief of the government, he could coordinate upholders, ministries, state institutions and supporting institutions, moreover, as chief of state, he should coordinate external organization and NGOs. This 
coordination will make a grand strategy through face-to-face dialog among stakeholders about overcoming the challenges and reaping the benefit of opportunities in eradicating corruption. This strategy is based on strategies made by KPK, upholders, the Ministry of PAN RB and it explains clearly the trajectory, time coverage, responsible stakeholders, and measurable objectives, leading to trust and commitment building. It will regulate corruption prevention and litigation in term of licence, internal auditors, budgeting, goods and service procurement. Its implementation will be funded by public finance and evaluated by internal and external auditors.

\section{REFERENCES}

[1] Agranoff, Robert. 2012. Collaborating to Manage: A Primer for the Public Sector. Washington, DC : Georgetown University Press.

[2] Creswell, John W. (2009). Research Design: Qualitative, Quantitative, and Mixed Methods Approaches.London: Sage Publications

[3] Larmour, Peter dan Nick Wolanin. (2013). Corruption and Anti Corruption. Canberra: ANU E Press

[4] Neuman, W. Lawrence. (2007). Basic of Social Research: Qualitative and Quantitative Approach. US: Pearson Education,Inc

[5] Ansell, Chris dan Alison Gash. (2007). Collaborative Governance in Theory and Practice. Journal of Public Administration Research and theory Advance Access, 2007. Page 1-22

[6] Emmerson, K, Nabatchi, T dan Balogh, S. (2011). An Integrative Framework for Collaborative Governance, Journal of Public Administration Research and Theory, 2011, Vol.22, hal.1-29.

[7] Republic of Indonesia. Law Number 20 of 2001 On Amendment of Law Number 31 of 1999 on Corruption Eradication. Statute Book of Republic of Indonesia Number 4150

[8] Adzkia, Aghnia. (2015). KPK Sidik Empat Polisi Kasus Simulator SIM. Downloaded at December 31th 2016. http://www.cnnindonesia.com/nasional/20150826114934-1274561/kpk-sidik-empat-polisi-kasus-simulator-sim/

[9] Haryadi, Dedi.(2016). Korupsi Audit. Downloaded at Desember 28 2016 http://www.bpk.go.id/news/korupsi-audit

[10] Maharani, Dian. (2012). Kronologi Penyelidikan Kasus Simulator Versi Polri. Downloaded at Desember 29th 2016. http://nasional.kompas.com/read/2012/08/04/10353221/kronologi.pen yelidikan.kasus.simulator.versi.polri

[11] Manafe, Dina. Target SDGs Bisa Gagal Tercapai Bila Korupsi Masih Merajalela. Downloaded at September 7th 2017. http://www.beritasatu.com/kesra/310678-target-sdgs-bisa-gagaltercapai-bila-korupsi-masih-merajalela.html

[12] Prasetiyo, Bagus. (2016). Soal Sumber Waras, KPK: Ada Penyimpangan, Belum Tentu Ada Korupsi. Downloaded at Desember 30th 2016 https://m.tempo.co/read/news/2016/06/20/078781601/soalsumber-waras-kpk-ada-penyimpangan-belum-tentu-ada-korupsi

[13] Rahman, Abdul. (2016). KPK Tetap Usut Sumber Waras, Ini Alasannya. Downloaded at Desember 29th 2016. https://m.tempo.co/read/news/2016/10/24/063814619/kpk-tetap-usutsumber-waras-ini-alasannya

[14] Transparency International. (2016). Corruption Perceptions Index 2015. Downloaded at November 6th 2016 www.transparency.org/cpi2015

[15] Transparency International. (2017). U4 Expert Answer: Coordination Mechanisms of Anti-Corruption Institutions. 